\title{
Conditional NF-L Transgene Expression in Mice for In Vivo Analysis of Turnover and Transport Rate of Neurofilaments
}

\author{
Stéphanie Millecamps, ${ }^{1,2}$ Geneviève Gowing, ${ }^{1}$ Olga Corti, ${ }^{3}$ Jacques Mallet, ${ }^{2}$ and Jean-Pierre Julien ${ }^{1}$ \\ ${ }^{1}$ Centre de Recherche du Centre Hospitalier de l'Université Laval, Department of Anatomy and Physiology of Laval University, Quebec, Canada G1V 4G2, \\ ${ }^{2}$ Centre National de la Recherche Scientifique Unité Mixte de Recherche 7091, Université Pierre et Marie Curie-Paris 6, Hôpital de la Pitié-Salpêtrière, 75013 \\ Paris, France, and ${ }^{3}$ Institut National de la Santé et de la Recherche Médicale U679, Hôpital de la Pitié-Salpêtrière, 75651 Paris, Cedex 13, France
}

We generated mice with doxycycline control of a human neurofilament light (NF-L) transgene in the context of the absence (tTA; hNF-L; NF- $\mathrm{L}^{-1-}$ ) or presence (tTA;hNF-L;NF-L ${ }^{+/-}$) of endogenous mouse NF-L proteins. Doxycycline treatment caused the rapid disappearance of human NF-L (hNF-L) mRNA in tTA;hNF-L mice, but the hNF-L proteins remained with a half-life of 3 weeks in the brain. In the sciatic nerve, the disappearance of hNF-L proteins after doxycycline treatment occurred in synchrony along the sciatic nerve, suggesting a proteolysis of NF proteins along the entire axon. The presence of permanent NF network in tTA;hNF-L;NF-L ${ }^{+/-}$mice further stabilized and extended longevity of hNF-L proteins by several months. Surprisingly, after cessation of doxycycline treatment, there was no evidence of leading front of newly synthesized hNF-L proteins migrating into sciatic nerve axons devoid of NF structures. The hNF-L proteins detected at weekly intervals reappeared and accumulated in synchrony at similar rate along nerve segments, a phenomenon consistent with a fast hNF-L transport into axons. We estimated the hNF-L transport rate to be of $\sim 10 \mathrm{~mm} / \mathrm{d}$ in axons devoid of NF structures based on the use of an adenovirus encoding tet-responsive transcriptional activator to transactivate the hNF-L transgene in hypoglossal motor neurons. These results provide in vivo evidence that the stationary NF network in axons is a key determinant of half-life and transport rate of NF proteins.

Key words: neurofilaments; axonal transport; turnover; doxycycline; transgenic; proteolysis

\section{Introduction}

Neurofilaments (NFs) are the most abundant cytoskeletal component in mature neurons. Three proteins termed light (NF-L; 68 $\mathrm{kDa})$, midsize (NF-M; $150 \mathrm{kDa}$ ), and heavy (NF-H; $200 \mathrm{kDa}) \mathrm{NF}$ subunits copolymerized to form $10 \mathrm{~nm}$ intermediate filaments (IFs) in axons. NFs are obligate heteropolymers requiring NF-L with NF-M or NF-L with NF-H for polymer formation (Ching and Liem, 1993; Lee et al., 1993). In the CNS, $\alpha$-internexin can also copolymerize with NF proteins (Yuan et al., 2006b). After their assembly in the perikaryon, NFs are slowly transported unidirectionally to the nerve endings with the slow component a (SCa) at a rate of $0.1-1 \mathrm{~mm} / \mathrm{d}$ toward the nerve terminal where they undergo proteolytic breakdown (Hoffman and Lasek, 1975). This classical model is based on pulse chase radiolabeled techniques performed on different kinds of axons including motor axons (spinal, hypoglossal, and oculomotor) and sensory nerves (dorsal root ganglion, olfactory, and optic) (for review, see Lasek

Received Dec. 7, 2006; revised March 6, 2007; accepted March 27, 2007.

This work was supported by the Canadian Institutes of Health Research and the National Institutes of Health. S.M. was supported by the Fondation pour la Recherche Médicale and was awarded by the Fondation Liliane BettencourtSchueller Price. J.-P.J. is a Canada Research Chair in Neurodegeneration. The technical help of Geneviève Soucy, Roxanne Larivière, Mélanie Simard, Jean-Nicolas Audet, and Daniel Houle is gratefully acknowledged. We thank Dr. Stanley Prusimer (University of California, San Francisco, San Francisco, CA) for the kind gift of Tg(tTA) mice.

Correspondence should be addressed to Jean-Pierre Julien, Research Centre of Centre de Recherche du Centre Hospitalier de I'Université Laval, Department of Anatomy and Physiology, Laval University, 2705 Boulevard Laurier, Quebec, Canada G1V 4G2. E-mail: jean-pierre.julien@crchul.ulaval.ca.

D01:10.1523/JNEUROSCI.5299-06.2007

Copyright $\odot 2007$ Society for Neuroscience $\quad$ 0270-6474/07/274947-10\$15.00/0 et al., 1992; Millecamps and Julien, 2004). However, time-lapse microscopy of fluorescently tagged NF proteins expressed in culture of sympathetic neurons recently challenged the traditional concept of slow axonal transport of NFs. The live-cell imaging studies in vitro revealed a fast transport of tagged-NFs of rates up to $2 \mu \mathrm{m} / \mathrm{s}$ interrupted by long pauses (Roy et al., 2000; Wang et al., 2000). Thus, the current view is that NFs are transported bidirectionally in the axon along microtubules through motors like kinesin and dynein (Brown, 2000). The average rate of movement is slow, because NF structures spend most of their time pausing in the axon. Under steady state conditions, the stationary pool of NFs constitutes the larger portion of NF network (Nixon and Logvinenko, 1986). Yabe et al. (2000) reported that phosphorylation of NFs resulted in their dissociation from the kinesin motor (Yabe et al., 2000). Little is known about factors that control the deposition of moving NFs into a stationary pool of NFs along axons and the lengths of time spent into stationary phase. There is evidence for slower transport rates of NFs in axons with the largest caliber (Hoffman et al., 1984), implying that the proportion of NFs that are stationary may vary in different neuronal types (Nixon and Logvinenko, 1986). Radiolabeling of newly synthesized NF proteins after intravitreally injection of $\left[{ }^{3} \mathrm{H}\right]$ proline suggested two phases of NF disappearance in RGC axons, one with protein half-life of $\sim 20 \mathrm{~d}$ and a second phase with slower half-life of $55 \mathrm{~d}$ (Nixon and Logvinenko, 1986). Moreover, there was a $6-9 \%$ peak of radiolabled proteins that lasted several months. The mechanisms of turnover of NFs in vivo are basically 
unknown. Proteases with affinity to NF proteins, including calcium-activated proteases, are present in axons. However, it is unknown to what extent proteolysis of NF proteins occurs at the synapse and/or locally along the axons in vivo.

To further investigate in vivo the turnover and axonal transport of NFs, we generated mice with doxycycline control of human neurofilament light (hNF-L) transgene in the presence or absence endogenous mouse NF-L proteins.

\section{Materials and Methods}

Generation of $t$ TA; $h N F-L ; N F-L^{-/-}$mice. We generated Tg(hNF-L) transgenic mice having the hNF-L gene under the control of a tetracycline (tet)-responsive promoter. The pUHD10.3 plasmid contains this tet promoter consisting of a minimal human cytomegalovirus promoter fused to seven copies of the $19 \mathrm{bp}$ inverted repeat tetracycline operator $($ tet $\mathrm{O})$ sequences (Gossen and Bujard, 1992). The original vector was modified by ligating the double-strand DNA linker 5'-TCGATATCGCGGCCGCGTCGACTCGA-3' (designed to insert restriction sites for EcoRV, NotI, and SalI into the XhoI digested pUHD-10.3) to obtain the pUHD-10.3 modified vector. The $4.5 \mathrm{~kb} X b a \mathrm{I}$ fragment of the human NF-L gene was inserted into the $\mathrm{XbaI}$ site of the pUHD-10.3 modified plasmid upstream from the SV40 polyadenylation site.

A $5.6 \mathrm{~kb} E c o \mathrm{RV} / \mathrm{SapI}$ fragment containing the tet inducible promoter, the hNF-L gene, and the SV40 polyadenylation site was microinjected into fertilized $\mathrm{C} 57 \mathrm{Bl} / 6 \times \mathrm{C} 3 \mathrm{H}(\mathrm{B} 6 \mathrm{C} 3 / \mathrm{F} 1)$ mouse eggs and then implanted into pseudopregnant females. Potential founders and $\operatorname{Tg}($ hNF-L) offspring were identified by Southern blot analysis as reported previously (Cote et al., 1993) using a $0.9 \mathrm{~kb}$ BglII fragment of the $\mathrm{hNF}-\mathrm{L}$ gene as a probe. This probe detected the transgene as a $3 \mathrm{~kb}$ band from BamHI-digested genomic DNA obtained from tail samples (see Fig. $1 B$ ). The number of copies was estimated by Southern blot analysis using serial dilution of DNA. The intensity of the bands was compared by densitometric analysis.

The $\operatorname{Tg}(\mathrm{tTA})$ mice overexpressing the tet-responsive transcriptional activator (tTA) from the prion promoter were kindly provided by Dr. Stanley Prusimer (Tremblay et al., 1998). An EcoRI/BamHI fragment of the pTet-Off vector (BD Biosciences Clontech, Mississauga, Ontario, Canada) was used as a probe for genotyping these mice. This probe detected a $1.3 \mathrm{~kb}$ band from Bam HI-digested genomic DNA obtained from tail samples (see Fig. $1 B$ ).

$\operatorname{Tg}($ hNF-L) and $\operatorname{Tg}$ (tTA) lines were crossed twice with NF-L knockout (NF-L ${ }^{-1-}$ ) mice (Zhu et al., 1997) to obtain (hNF-L;NF-L ${ }^{-1-}$ ) and $\left(\mathrm{tTA}^{\mathrm{N} F-\mathrm{L}^{-1-}}{ }^{-}\right.$mice, respectively (see Fig. $1 \mathrm{~A}$ ). A $1.5 \mathrm{~kb}$ XhoI/BamHI fragment from pQZ10LB plasmid (Zhu et al., 1997) detected a $10.7 \mathrm{~kb}$ band as the normal allele for NF-L and a $4.6 \mathrm{~kb}$ band as the $-/-$ allele with BamHI-digested genomic DNA obtained from tail samples (see Fig. $1 B$ ). In a last step, (hNF-L;NF-L ${ }^{-1-}$ ) and (tTA;NF-L ${ }^{-1-}$ ) mice were bred together to obtain (tTA;hNF-L;NF-L ${ }^{-1-}$ ) mice (see Fig. $1 A$ ).

Tissue collections. The use of animals described in this study meet The Guide to the Care and Use of Experimental Animals of the Canadian Council on Animal Care. The mice were killed by overdose $(1 \mathrm{~g} / \mathrm{kg})$ of chloral hydrate (Fisher Scientific, Nepean, Ontario, Canada). The brain, cerebellum, spinal cord, kidney, and heart were removed. The right and left sciatic nerves and L5 ventral and dorsal roots were also dissected out. The sciatic nerve was cut into $6 \mathrm{~mm}$ consecutive segments starting from the L5 dorsal root ganglion to the muscular extremity. After dissection, tissue was immediately frozen in liquid nitrogen and stored at $-80^{\circ} \mathrm{C}$ until protein or RNA extraction.

Northern blot analyses. Total RNAs were extracted using the Trizol reagent (Invitrogen, Burlington, Ontario, Canada). Total RNA (20 $\mu \mathrm{g})$ was separated on $1 \%$ agarose-formaldehyde gel, transferred on GeneScreen Neutral Hybridization Transfer Membrane (PerkinElmer, Woodbridge, Ontario, Canada) and probed with the hNF-L probe. The same membrane was stripped and probed with the tTA probe or an actin probe.

Semiquantitative reverse transcription-PCR. Total RNA was extracted using RNeasy Mini kit (Qiagen, Mississauga, Ontario, Canada) according to the manufacturer instructions. Total RNA (500 ng) was treated with $1 \mathrm{U}$ of RQ1 DNase (Promega, Madison, WI) that was then inactivated for $5 \mathrm{~min}$ at $90^{\circ} \mathrm{C}$.

First-Strand cDNA synthesis was performed using Superscript II reverse transcriptase (Invitrogen) according to the manufacturer protocol. PCR was performed with TaqDNA polymerase (Promega) with the following primers: 5'-CAGCTTCATCGAGCGCGTGC-3' and 5'CGTCGGTGTTCTTGGCGGC-3' for NF-L amplification and $5^{\prime}$ GTGGGCCGCTCTAGGCACCAA- ${ }^{\prime}$ and $5^{\prime}$-CTCTTTGATGTCACGCACGATTTC- $3^{\prime}$ for actin. The PCR conditions were as follows: $94^{\circ} \mathrm{C}, 2$ min, and 24 cycles $\left(94^{\circ} \mathrm{C}, 30 \mathrm{~s} ; 58^{\circ} \mathrm{C}, 45 \mathrm{~s} ; 72^{\circ} \mathrm{C}, 30 \mathrm{~s}\right)$.

Western blot analyses. Tissues were homogenized using a Polytron PT1200C (Kinematica, Lucerne, Switzerland) in a lysis buffer containing $50 \mathrm{~mm}$ Tris- $\mathrm{HCl}, \mathrm{pH} 8,150 \mathrm{~mm} \mathrm{NaCl}, 5 \mathrm{~mm}$ EDTA, 2\% SDS, a mixture of protease inhibitors (aprotinin, leupeptin, and pepstatin), and $1 \mathrm{~mm}$ sodium orthovanadate. Tissue extracts were centrifuged at 13,000 rpm for $10 \mathrm{~min}$, and protein concentration of supernatants was estimated by the bicinchoninic acid assay (Sigma, Oakville, Ontario, Canada). Twenty micrograms of proteins were separated on $8 \%$ SDS-polyacrylamide gels and transferred electrophoretically to nitrocellulose membranes. Membranes were incubated with primary antibodies in PBS containing 5\% milk and $0.1 \%$ Tween 20 overnight at $4^{\circ} \mathrm{C}$ followed by $1 \mathrm{~h}$ of incubation with appropriate peroxidase-conjugated secondary antibodies. Signals were detected using Western Lightning Chemiluminescence Reagent (PerkinElmer) and Biomax radiographic film (Kodak, Rochester, NY). Densitometric analysis was performed using AIDA/2D version 2.43 software.

Antibodies. The human NF-L protein was detected using a monoclonal antibody (clone DP5-112) developed by Denise Paulin (Institut Pasteur, Paris, France). Monoclonal antibody recognizing NF-H (N52 clone) was obtained from Sigma. Antibodies recognizing actin (monoclonal MAB1501), NF-H (monoclonal MAB5262; polyclonal AB1982), NF-M (monoclonal MAB5254; polyclonal AB1981), NF-L (polyclonal AB1983), and peripherin (monoclonal MAB1527, polyclonal AB1530) were purchased from Chemicon (Temecula, CA). The peroxidaseconjugated anti-rabbit (made in donkey) and anti-mouse (made in goat) were obtained from Jackson ImmunoResearch (Mississauga, Ontario, Canada). Alexa Fluor goat anti-rabbit and anti-mouse IgG were obtained from Invitrogen (Eugene, OR).

Immunohistological analyses. Mice were anesthetized by chloral hydrate and perfused with $4 \%$ paraformaldehyde (PFA) in PBS, pH 7.4. Brain, spinal cords, and ventral and dorsal roots were dissected out, postfixed for $2 \mathrm{~h}$ with the fixative, cryoprotected for $2 \mathrm{~d}$ in PBS containing $30 \%$ sucrose, and frozen at $-80^{\circ} \mathrm{C}$. Sections $(20 \mu \mathrm{m})$ were cut using a cryostat. Slides were incubated for $30 \mathrm{~min}$ in PBS containing $0.2 \%$ gelatin and $0.3 \%$ hydrogen peroxide. After three consecutive washes in PBS, sections were incubated in a blocking solution ( $10 \%$ goat serum, $0.2 \%$ gelatin, $0.3 \%$ Triton X-100 in PBS) for $1 \mathrm{~h}$. All antibodies were diluted in the blocking solution, and incubation was performed overnight at room temperature. After four consecutive washes in PBS, the primary antibody was detected either using biotinylated anti-mouse IgG and the avidinbiotin peroxidase complex (Vector Laboratories) with 3,3'diaminobenzidine (Sigma) as the chromogenic substrate or using fluorescently labeled Alexa Fluor secondary antibodies.

In situ hybridization analyses. Mice were deeply anesthetized by chloral hydrate and perfused with 4\% PFA in $0.1 \mathrm{~m}$ borax buffer $(\mathrm{pH} 9.5$, at $4^{\circ} \mathrm{C}$ ). Brains and spinal cords were dissected out and cryoprotected for $2 \mathrm{~d}$ in the fixative solution containing $10 \%$ sucrose. The frozen brains were cut on a microtome. The $25 \mu \mathrm{m}$ sections were collected in a cold cryoprotectant solution containing $0.05 \mathrm{~m}$ sodium phosphate, $\mathrm{pH} 7.3,30 \%$ ethylene glycol, and $20 \%$ glycerol and stored at $-20^{\circ} \mathrm{C}$. Hybridization was performed on every sixth section of the brain using ${ }^{35} \mathrm{~S}$-labeled cRNA probes (detailed below). All solutions were treated with diethylpyrocarbonate (Depc) and sterilized to prevent RNA degradation.

Sections were mounted on gelatin and poly-L-lysine-coated slides, dried overnight under vacuum, fixed in $4 \%$ PFA for $20 \mathrm{~min}$, and digested at $37^{\circ} \mathrm{C}$ for $25 \mathrm{~min}$ with proteinase $\mathrm{K}(10 \mu \mathrm{g} / \mathrm{ml}$ diluted in $0.1 \mathrm{M}$ Tris, $\mathrm{pH}$ 8 , and $50 \mathrm{~mm}$ EDTA). Sections were rinsed in Depc-treated water and then in $0.1 \mathrm{~m}$ triethanolamine (TEA) $\mathrm{pH} 8$, were acetylated in TEA con- 
A
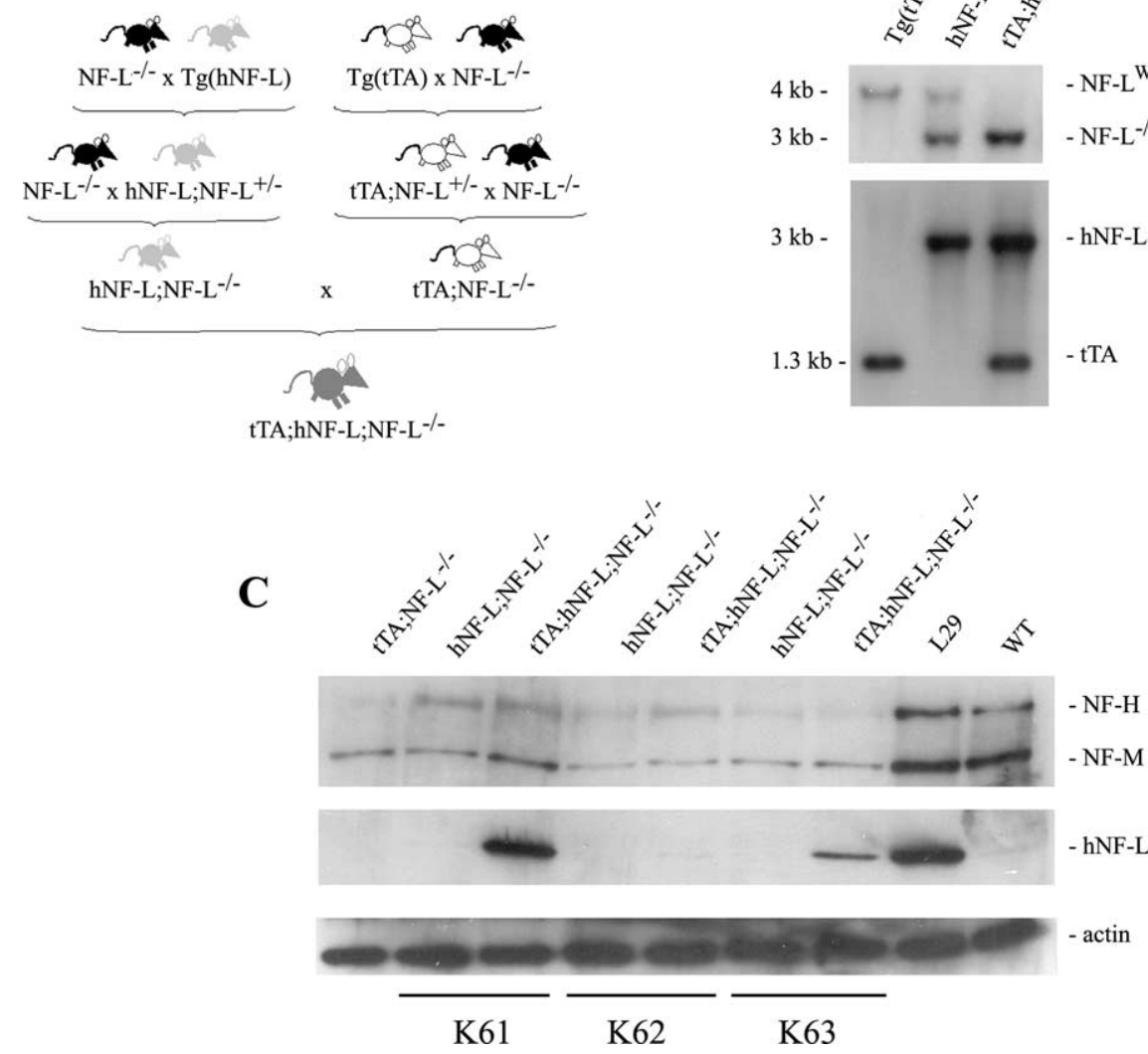

Figure 1. Creation of mice with doxycycline control of hNF-L transgene. $A$, Schematic representation of the successive steps to generate the (tTA; $\mathrm{hNF}-\mathrm{L} ; \mathrm{NF}-\mathrm{L}^{-1-}$ ) mice. $\boldsymbol{B}$, Southern blot analysis of genomic tail DNA digested with BamHl and hybridized with three ${ }^{32} \mathrm{P}$-labeled probes. Bands of 1.3 and/or $3 \mathrm{~kb}$ were detected with $\mathrm{TTA}$ and $\mathrm{hNF}-\mathrm{L}$ probe, respectively, in transgenic mice carrying one or both transgenes. A mNF-L probe was used to identify mice that were knock-out (NF- $\mathrm{L}^{-1-}$ ) or heterozygous $\left(\mathrm{NF}-\mathrm{L}^{+/-}\right.$) for endogenous NF-L gene. Examples of genotypes depicted in $\boldsymbol{B}$ are Tg(tTA), (hNF-L;NF-L ${ }^{+/}$), and (tTA;hNF-L;NF$\mathrm{L}^{-1-}$ ) for the first, second, and last lane, respectively. C, Western blot analysis of total brain protein extracts of the three transgenic lines K61, K62, and K63. The line K61 presented the higher level of hNF-L expression transactivated by the tTA. A protein extract from the previously reported L29 hNF-L transgenic mice (Julien et al., 1987) was loaded as a positive control for hNF-L detection.

taining $0.25 \%$ acetic anhydride and dehydrated in increasing concentration $(50-100 \%)$ of ethanol. After being dried under vacuum, the slides were incubated overnight at $60^{\circ} \mathrm{C}$ with $90 \mu \mathrm{l}$ of hybridization solution (see below). Sections were washed in $4 \times$ SSC and treated for $30 \mathrm{~min}$ by RNase $(20 \mu \mathrm{g} / \mathrm{ml})$. After rinses in decreasing concentrations of SSC (2$0.5 \times)$ at room temperature, sections were washed for $30 \mathrm{~min}$ at $60^{\circ} \mathrm{C}$ in $0.1 \times$ SSC, dehydrated in increasing concentrations of ethanol, and dried under vacuum. Sections were exposed to Biomax film (Kodak) for $2 \mathrm{~d}$. After defatting in xylene, slices were dipped into NTB2 nuclear emulsion (Kodak), exposed for $14 \mathrm{~d}$, developed in D19 developer (Kodak), fixed in rapid fixer (Kodak), and counterstained with eosin after being mounted in distrene plasticizen xylene mounting medium.

For cRNA probe synthesis, a $4.5 \mathrm{~kb}$ XbaI hNF-L fragment was subcloned into the PRc/CMV plasmid (Invitrogen) between T7 and Sp6 promoters. ${ }^{35} \mathrm{~S}$-labeled cRNA probes were synthesized by incubation of 250 ng of linearized plasmid (with XhoI and T7 or Sp6 primers for sense and antisense riboprobe, respectively) in $40 \mathrm{~mm}$ Tris, $\mathrm{pH} 7.9$, containing $6 \mathrm{~mm} \mathrm{MgCl}_{2}, 2 \mathrm{~mm}$ spermidine, $10 \mathrm{~mm} \mathrm{NaCl}, 10 \mathrm{~mm}$ dithiothreitol (DTT), $0.2 \mathrm{mM}$ ATP-GTP-CTP, $100 \mu \mathrm{Ci}$ of $\alpha$ - ${ }^{35} \mathrm{~S}$-UTP (\#NEG 039H; DuPont NEN, Boston, MA), 20 U of RNasin (Promega) and $10 \mathrm{U}$ of T7 or Sp6 RNA polymerase for $60 \mathrm{~min}$ at $37^{\circ} \mathrm{C}$. One hundred microliters of DNase solution (containing $10 \mathrm{~mm}$ Tris, $10 \mathrm{mM} \mathrm{MgCl}_{2}, 10 \mathrm{U}$ of DNase, and $25 \mu \mathrm{g}$ of tRNA) was then added to the probe during $10 \mathrm{~min}$. The unincorporated nucleotides were removed by a phenol/chloroform extraction and ammonium acetate precipitation. The probe $\left(10^{7} \mathrm{cpm}\right)$ was diluted in hybridization solution (10 mM Tris, pH 8, $0.3 \mathrm{~m} \mathrm{NaCl}, 1 \mathrm{~mm}$ EDTA, 10 mм DTT, Denhart's solution, $50 \%$ formamide, $10 \%$ Dextran sulfate, $0.5 \mathrm{mg}$ tRNA) and was heated for $10 \mathrm{~min}$ at $65^{\circ} \mathrm{C}$ before being spotted on slides.

Adenovirus injection. The E1/E3-deleted adenoviral construct (Ad-tTA) expressing the tTA under the control of the mouse phosphoglycerate kinase promoter was generated by homologous recombination and amplified in E1 transcomplementing 293 cell line as detailed previously (Corti et al., 1999). The concentration of the viral stock determined using a standard plaque assay procedure was $2 \times 10^{7}$ particle forming unit $(\mathrm{pfu}) / \mu \mathrm{l}$. Intramuscular injection of Ad-tTA into the mouse tongue $\left(2 \times 10^{8} \mathrm{pfu} / \mathrm{mouse}\right)$ was performed as described previously (Millecamps et al., 1999). Mice received tetracycline hydrochloride (Sigma) in drinking water $(0.5 \mathrm{mg} / \mathrm{ml}$ in $3 \%$ sucrose) until being killed to avoid expression of hNF-L in muscle cells. Mice were killed by overdose ( $1 \mathrm{~g} / \mathrm{kg}$ ) of chloral hydrate $2-5 \mathrm{~d}$ after adenoviral injection and transcardial perfusion with PBS. The right and the left branches of the hypoglossal nerve were collected. This total nerve fragment $(12 \mathrm{~mm}$ ) was divided in a proximal portion (to the motor neuron cell bodies) and a distal portion of $6 \mathrm{~mm}$ each that were frozen in liquid nitrogen and stored at $-80^{\circ} \mathrm{C}$ until protein extraction.

\section{Results \\ Production of (tTA;hNF-L;NF-L ${ }^{-/-}$) transgenic mice}

We generated transgenic mice with controlled expression of hNF-L taking advantage of the Tet-off tetracycline-regulated system (Gossen and Bujard, 1992). First, the hNF-L gene was placed under the control of the Tet-off promoter to establish $\operatorname{Tg}(\mathrm{hNF}-\mathrm{L})$ transgenic mice. Three $\mathrm{Tg}(\mathrm{hNF}-\mathrm{L})$ lines were obtained and were numbered G61, G62, and G63. The number of copies in each transgenic line was evaluated on Southern blot analysis. Densitometric analysis estimated that mice from lines G61, G62, and G63 carry 40, 4, and 12 copies of the hNF-L transgene, respectively (data not shown). In these mice, hNF-L expression was expected to occur after the coexpression of the tTA and to be prevented by addition of tetracycline analogs in drinking water.

The $\operatorname{Tg}(\mathrm{tTA})$ mice expressing the tTA from the prion promoter were kindly provided by Dr. Patrick Tremblay (Tremblay et al., 1998). The $\mathrm{Tg}(\mathrm{hNF}-\mathrm{L})$ lines and $\mathrm{Tg}(\mathrm{tTA})$ mice were crossed twice with NF-L knock-out (NF-L ${ }^{-1-}$ ) mice (Zhu et al., 1997) to obtain three lines of (hNF-L;NF-L ${ }^{-1-}$ ) referred to as K61, K62, or K63 lines for convenience and ( $\mathrm{tTA} ; \mathrm{NF}^{-\mathrm{L}^{-/}}{ }^{-}$), respectively. These transgenic lines were devoid of endogenous NF-L gene. Finally, we bred (hNF-L;NF-L ${ }^{-1-}$ ) mice with (tTA;NF-L ${ }^{-1-}$ ) mice to obtain double transgenic (tTA;hNF-L;NF-L ${ }^{-\prime-}$ ) mice (Fig. 1A). 


\section{hNF-L expression in}

(tTA;hNF-L;NF-L ${ }^{-/-}$) mice

We first examined the ability of the tTA to activate the expression of hNF-L in the three double (tTA;hNF-L;NF-L ${ }^{-1-}$ ) transgenic lines. Immunoblots with antihuman NF-L monoclonal antibody (DP5-112) using protein extracts from total brain revealed that hNF-L expression was detected at much higher levels in double (tTA;hNF-L;NF-L ${ }^{-1-}$ ) transgenic mice than in the corresponding single (hNF-L;NF-L ${ }^{-/-}$) mice (Fig. 1C). The presence of tTA activated the expression of hNF-L in each line. Because the mouse line K61 exhibited the highest level of hNF-L expression, we selected this line for expansion and for the following studies.

The levels of hNF-L protein in this K61 line (tTA;hNF-L;NF-L ${ }^{-1-}$ ) were compared in various tissues. Western blot analysis showed that hNF-L was expressed in the forebrain, cerebellum, spinal cord, and sciatic nerve (Fig. $2 \mathrm{~A}$ ). As determined by densitometric analysis of immunoblots, the signals were 5- to 10-fold higher for (tTA; hNF-L;NF-L ${ }^{-1-}$ ) than for (hNF$\mathrm{L} ; \mathrm{NF}-\mathrm{L}^{-1-}$ ) mice. Increased levels of both NF-M and NF-H were observed in double transgenic mice as a consequence of hNF-L expression in these tissues. No hNF-L expression was detected in kidney or heart in our mice in contrast to a previous study that reported a high level of transgene expression in heart using the mouse prion promoter in transgenic mice (Borchelt et al., 1996).

To identify the cellular types expressing hNF-L in (tTA;hNF-L;NF-L ${ }^{-/-}$) mice, double immunofluorescence analysis was performed on the cerebellum, hippocampus, and sciatic nerve. The hNF-L colocalized with NF-M in mossy fibers of the hippocampus (Fig. 2I). In the cerebellum, hNF-L partially colocalized with NFM-positive cells (Fig. 2 F) and was also expressed in $\alpha$-internexin-positive parallel fibers of the granular cells (Fig. 2G). In contrast, hNF-L did not colocalize with Bergman glia stained with glial fibrillary acidic protein (GFAP) antibody (Fig. $2 H$ ). In the sciatic nerve, hNF-L was detected in some NF-M-positive fibers (Fig. $2 J$ ). Double immunofluorescence on ventral and dorsal roots revealed that hNF-L was mostly expressed in the sensory tract (Fig. $2 \mathrm{~K}$ ).

\section{Regulation of hNF-L expression in vivo by} doxycycline treatment

The possibility of regulating hNF-L expression in adult mice was assessed by analyzing hNF-L mRNA levels after doxycycline treatment. This tetracycline analog is highly absorbed after oral route administration, and its half-life is longer than that of tetracycline. It is more lipophilic than tetracycline facilitating its passage through the blood barrier (Sande and Mandell, 1990), and it was extensively used to modulate gene expression in mouse brain

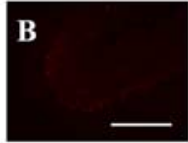

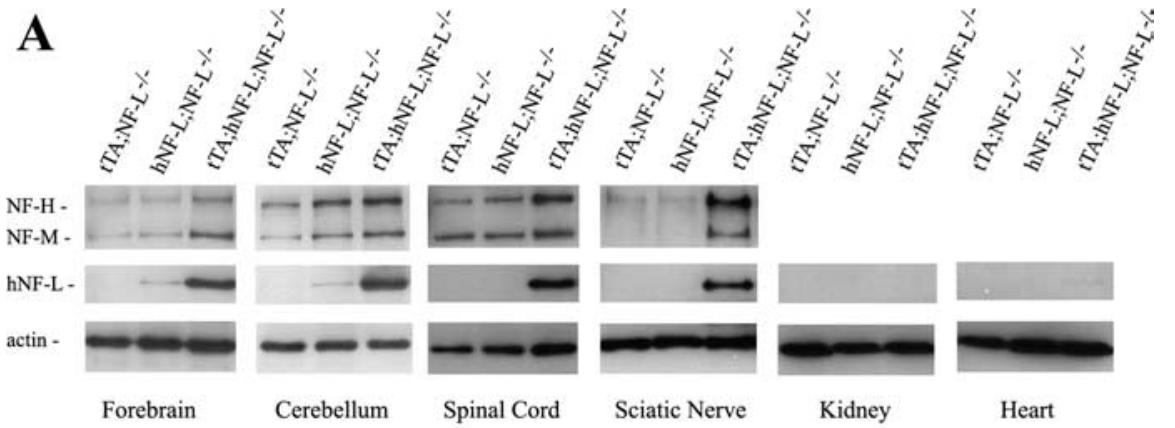

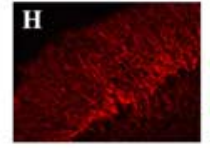

tTA;hNF-L;NF-L ${ }^{-/-}$
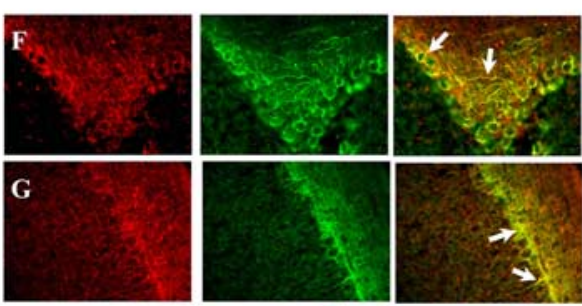

Cerebellum
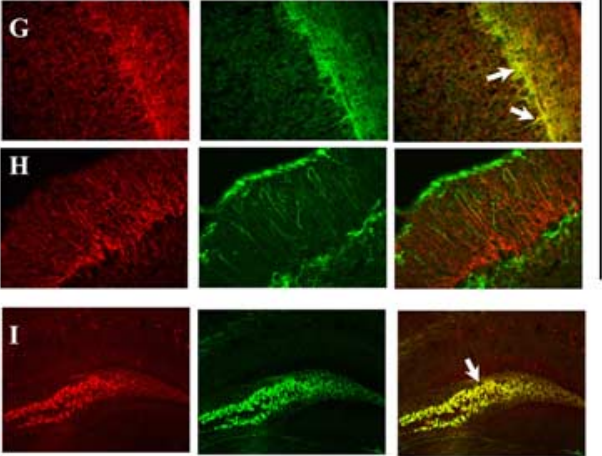

Hippocampus
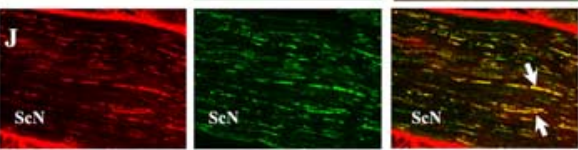

Sciatic Nerve
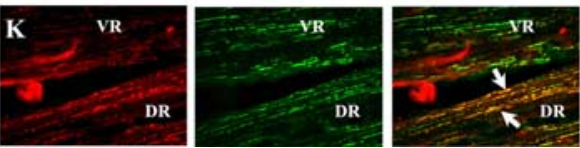

Ventral and

Dorsal Roots

Figure 2. Expression of NF-L protein in (tTA;hNF-L;NF- $\mathrm{L}^{-1-}$ ) mice. $\boldsymbol{A}$, Western blot analysis showing expression of hNF-L protein in various tissues from (tTA;NF-L $\mathrm{L}^{-1-}$ ), (hNF-L;NF- $\mathrm{L}^{-1-}$ ), and (tTA;hNF-L;NF-L ${ }^{-1-}$ ) mice. $\boldsymbol{B}-\boldsymbol{E}$, Absence of hNF-L expression in NF-L ${ }^{-1-}$ mice was shown by immunofluorescence (red) using monoclonal $(\boldsymbol{B}, \boldsymbol{D}-\boldsymbol{E})$ or polyclonal $(\boldsymbol{C})$ anti-NF-L labeling for NF-L (red) and NF-M $(\boldsymbol{F}, \boldsymbol{I}-\boldsymbol{K}), \alpha$-internexin $(\boldsymbol{G}), \operatorname{or~GFAP~}(\boldsymbol{H})$ (all in green) in the cerebellum $(\boldsymbol{F}-\boldsymbol{H})$, hippocampus $(\boldsymbol{I})$, sciatic nerve $(\mathrm{ScN} ; \boldsymbol{J})$, and ventral root $(\mathrm{VR})$ and dorsal root $(\mathrm{DR})(\boldsymbol{K})$. In the cerebellum, hNF-L protein colocalized (arrows) with NF-M $(\boldsymbol{F})$ and $\alpha$-internexin $(\boldsymbol{G})$ but not with GFAP $(\boldsymbol{H})$. NF-L staining is superimposed (white arrows) with NF-M in the hippocampus (I) and in the sciatic $(\boldsymbol{J})$ and dorsal $(\boldsymbol{K})$ roots. Scale bar (in $\boldsymbol{B}): \boldsymbol{E}, \boldsymbol{K}, 100 \mu \mathrm{m} ; \boldsymbol{B}, \boldsymbol{D}, \boldsymbol{F}-\boldsymbol{H}, \boldsymbol{J}, 200 \mu \mathrm{m} ; \boldsymbol{C}, \boldsymbol{I}, 400 \mu \mathrm{m}$.

(Tremblay et al., 1998; Tanaka et al., 2006). Five- to 6-month-old (tTA;hNF-L;NF-L ${ }^{-l-}$ ) mice were treated daily by doxycycline addition in drinking water for $1-8$ weeks. Northern blot analysis was performed on cerebellum mRNA. NF-L mRNA was not detectable after 1 week of doxycycline treatment (Fig. $3 A$ ). To test whether it was possible to restore hNF-L expression, doxycycline administration was stopped on 8-week-treated animals. The hNF-L mRNA reappeared 2 weeks after removal of doxycycline, and at 4 weeks the level was similar to that of animals that had never received doxycycline (Fig. 3A). Radioactive in situ hybridization analysis using an oligonucleotide hybridizing hNF-L mRNA confirmed these results. No hNF-L mRNA was detected in cerebellum granular cells 2 weeks after the beginning of doxycycline treatment, and expression was reinduced 2 weeks after subsequent withdrawal of doxycycline (Fig. $3 B, C$ ). 
A
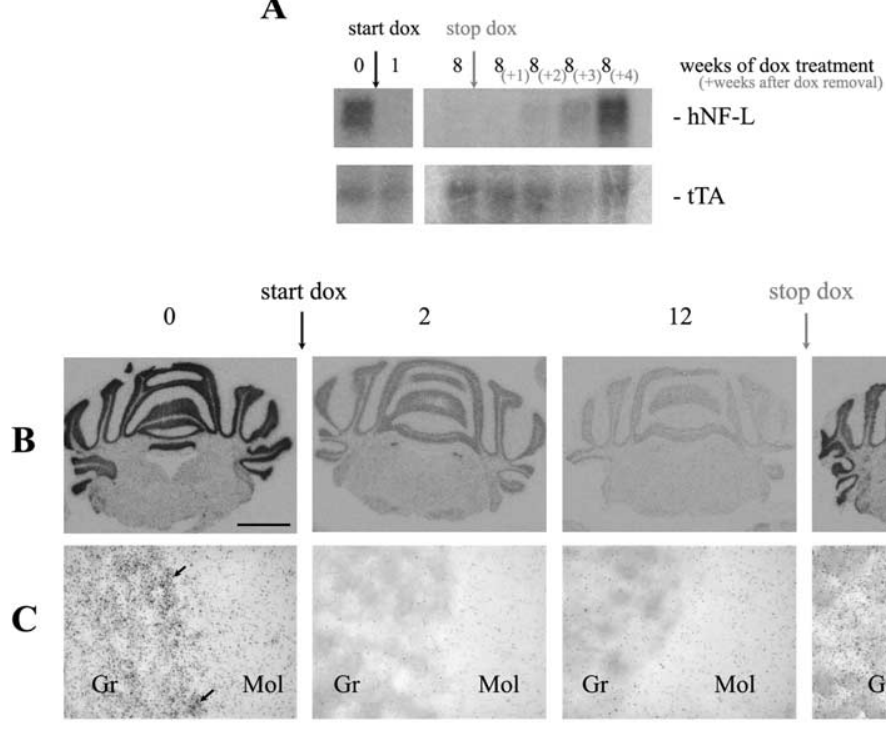

dox

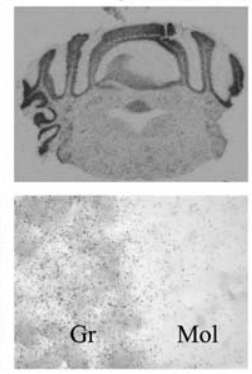

D

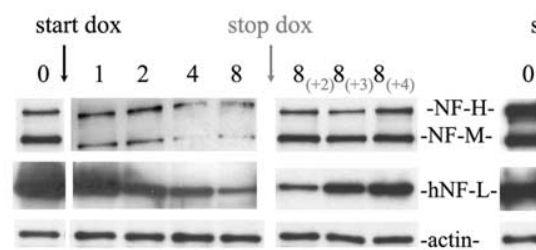

start dox

stop dox

$\begin{array}{llllllll}0 & 1 & 2 & 4 & 8 & \vdots & 8_{(+2)} 8_{(+3)} 8_{(+4)} & \\ & \text { weeks of dox }\end{array}$

\begin{tabular}{lllllllll}
0 & 1 & 2 & 4 & 8 & $8_{(+2)} 8_{(+3)} 8_{(+4)}$ & $\begin{array}{c}\text { weeks of dox } \\
(+ \text { weeks after dox } \\
\text { removal })\end{array}$ \\
\hline & & & & & & & &
\end{tabular}

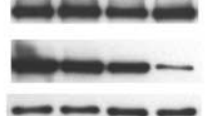

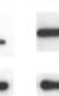

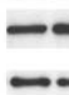

$\mathbf{E}$

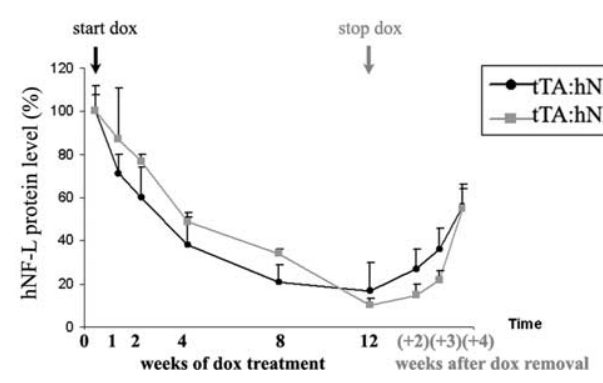

Figure 3. Half-life of hNF-L protein in the cerebellum. $A$, Northern blot of total RNA extracted from the cerebellum of (tTA; $h N F-$ $\mathrm{L} ; \mathrm{NF}-\mathrm{L}^{-1-}$ ) mice at several time points: before (first lane); 1 and 8 weeks after doxycycline (dox) addition in drinking water; and $1,2,3$ and 4 weeks after doxycycline removal. Note that NF-L mRNA disappeared 1 week after the beginning of doxycycline treatment and started to reappear 2 weeks after treatment cessation. $\boldsymbol{B}, \boldsymbol{C}$, In situ hybridization with hNF-L probe on coronal cerebellum sections during the course of doxycycline treatment. Pictures were taken from the $\mathrm{x}$-ray film in $\boldsymbol{B}$. Sections were then dipped in nuclear emulsion milk and counterstained with eosin in C. NF-L mRNA expression was detected in Purkinje cell layers (black arrows) and granular cell layers (Gr) but not in the molecular cell layer (Mol). Scale bar (in B): B, $1.5 \mathrm{~mm} ; \boldsymbol{C}, 75 \mu \mathrm{m} . \boldsymbol{D}$, Western blot analysis of cerebellum protein extracts from (tTA;hNF-L;NF-L ${ }^{-1-}$ ) mice (left) and (tTA;hNF-L;NF-L ${ }^{+-}$) mice (right). Note the progressive decline of NF-L protein level after the start up of doxycycline treatment and the progressive increase after treatment was stopped. $\boldsymbol{E}$, Densitometric analysis of NF-L protein level during the course of doxycycline treatment in cerebellum of (tTA; hNF-L;NF-L ${ }^{-I-}$ ) (black curve) and (tTA; hNF-L;NF-L ${ }^{+/-}$) (gray curve) mice. Results are means \pm SEM (SEM) of three to nine or two to five animals per time point for (tTA;hNF-L;NF-L ${ }^{-I-}$ ) mice and (tTA;hNF-L;NF- $\mathrm{L}^{+\prime-}$ ) mice, respectively.

\section{hNF-L half-life of 3 weeks in the brain}

To determine the half-life of hNF-L proteins in the CNS, cerebellum extracts from doxycycline-treated and nontreated mice were subjected to Western blot using anti-hNF-L antibody. The hNF-L band from (tTA;hNF-L;NF- $\mathrm{L}^{-\prime-}$ ) animals treated during $0,2,4$, and 8 weeks with doxycycline were analyzed by densitometry. The graph representation of hNF-L levels displayed a progressive decrease after the beginning of doxycycline administration (Fig. $3 E$ ). The data showed that immunodetection hNF-L signals in samples from mice with 2,4 , and 8 weeks of doxycycline treatment corresponded to 60,40 , and $20 \%$, respectively, of that found in untreated control animals (Fig. 3D,E). The hNF-L sig-
12 weeks of dox (+2 weeks after dox removal)

nal did not further decrease after one additional month of doxycycline administration. From these results, we estimate that the half-life of hNF-L is $\sim 3$ weeks in the cerebellum of (tTA;hNF-L;NF-L ${ }^{-1-}$ ) mice. The same analysis was performed with (tTA;hNF-L;NF-L ${ }^{+/-}$) mice heterozygous for endogenous mouse NF-L gene. The kinetic of hNF-L protein loss in the cerebellum was similar in these mice than that of (tTA;hNF-L;NF-L ${ }^{-1-}$ ) mice (Fig. 3D,E).

\section{Synchronized loss of hNF-L along the sciatic nerve}

To study the disappearance of hNF-L along the axon, we divided the entire sciatic nerve in $6 \mathrm{~mm}$ consecutive segments starting from the dorsal root ganglion (DRG). Similar to what was seen above in the cerebellum, the hNF-L levels gradually decreased in the sciatic nerve of (tTA; hNF-L;NF-L ${ }^{-1-}$ ) mice after doxycycline treatment. In the context of absence of stationary NFs (mouse NF- $\mathrm{L}^{-1-}$ ), the halflife of hNF-L proteins was $\sim 3$ weeks (Fig. $4 A-C)$. However, in the context of steady production of stationary NFs (tTA;hNFL;NF- $\mathrm{L}^{+/-}$), there was no detectable loss of hNF-L protein in sciatic nerve axons after 3 months of doxycycline administration (Fig. 4C). Actually, we detected no loss of hNF-L in these mice even after 4.5 months of doxycycline treatment. There was a loss of hNF-L after 8 months of treatment, but $35 \%$ of hNF-L protein was still remaining (data not shown). This demonstrates that the presence of stationary NF network in the axon is a major determinant of half-lives of NF proteins.

Another unexpected finding is that there was no moving wave of hNF-L along the sciatic nerve after suppression of hNF-L mRNA expression in ( $\mathrm{tTA}$; hNF-L;NF-L ${ }^{-1-)}$ mice. Instead, there was a synchronized loss of hNF-L signal in the successive sciatic nerve segments of the (tTA;hNF-L;NF-L ${ }^{-\prime-}$ ) mice (Fig. $4 B)$. These data would be consistent with proteolytic degradation of hNF-L proteins occurring along the entire sciatic nerve and not only restricted to nerve endings.

\section{Transport rate of NFs is faster in axons devoid of stationary NFs}

We used two strategies to address the axonal transport of NFs in these mice. First, we monitored the reappearance and accumulation of hNF-L protein along the sciatic nerve after doxycycline removal in (tTA;hNF-L;NF- $\mathrm{L}^{-1-}$ ) mice. The animals were administered doxycycline in drinking water for 3 months to ensure the disappearance of hNF-L. Then, the treatment was stopped, and the distribution of hNF-L proteins was assessed along the sciatic nerve during 4 weeks. Two weeks after cessation of doxy- 
cycline treatment, the hNF-L protein reappeared and accumulated slowly in the sciatic nerve of (tTA;hNF-L;NF-L ${ }^{-1-}$ ) mice (Fig. 4E).

Surprisingly, the reappearance and the accumulation of hNF-L occurred in apparent synchrony along the axon within 1 week (Fig. 4D). Note that there was no wavefront of hNF-L proteins moving along the sciatic nerve segments as anticipated from classical radiolabeling of newly synthesized NF proteins in axons observed at 1 week intervals. This suggests that a fast rather than slow axonal transport of hNF-L proteins occurred in sciatic nerve axons that lack stationary NF network in (tTA;hNF-L;NF-L ${ }^{-/-}$) mice.

Second, to further confirm this result, we studied axonal transport of hNF-L protein in the motor hypoglossal nerve. An adenoviral vector encoding the tTA was injected in the tongue of (hNF-L;NF$\mathrm{L}^{-/-}$) mice to transactivate hNF-L expression in the motor neurons of the hypoglossal nucleus (Fig. 5A). The adenoviral vectors were retrogradely transported along the motor nerve innervating the injected muscle, and hNF-L transgene expression became detectable in cell bodies of motor neurons $2 \mathrm{~d}$ after viral administration (Finiels et al., 1995; Ghadge et al., 1995).We previously used this technique with success to deliver transgenes in motor neurons of the hypoglossal nucleus (Millecamps et al., 1999, 2001). Here, to avoid any transactivation of hNF-L expression in muscle cells, tetracycline was added in drinking water of the injected mice. Orally administered tetracycline does not cross the blood barrier (Sande and Mandell, 1990) and is thus a mean to steer clear of the expression of hNF-L in the muscle while preserving that should occur in the motor neurons located in the brainstem.

We first tested whether intralingual administration of Ad-tTA vector could trigger hNF-L expression in the motor neurons of (hNF-L;NF-L ${ }^{-1-}$ ) mice. As shown in Figure $5 B$, the expression level of hNF-L protein was strongly increased in the brainstem $2 \mathrm{~d}$ after Ad-tTA inoculation. To follow hNF-L as it was transported down the $12 \mathrm{~mm}$ of the hypoglossal nerve, the two branches of the XII cranial nerve were collected and divided in proximal (close to the motor neuron soma) and distal (close to the motor nerve endings) segments of $6 \mathrm{~mm}$ each (Fig. 5A). At a transport rate of $\sim 1 \mathrm{~mm} / \mathrm{d}$ in hypoglossal axons (Bizzi et al., $1984)$, the NF proteins would normally take $6 \mathrm{~d}$ to enter the distal $6 \mathrm{~mm}$ segment of the hypoglossal nerve, plus an additional $6 \mathrm{~d}$ to reach the nerve terminal. Instead of expected $8-10 \mathrm{~d}$ for initial detection of hNF-L after the tTA expression, the hNF-L band was already detectable in the distal segment of hypoglossal nerve on the same day (day 2) this protein appeared in motor neuron cell bodies (Fig. $5 B, C$, black arrow). Two days later, the majority of

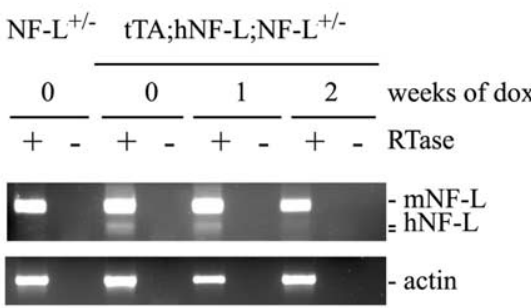

C
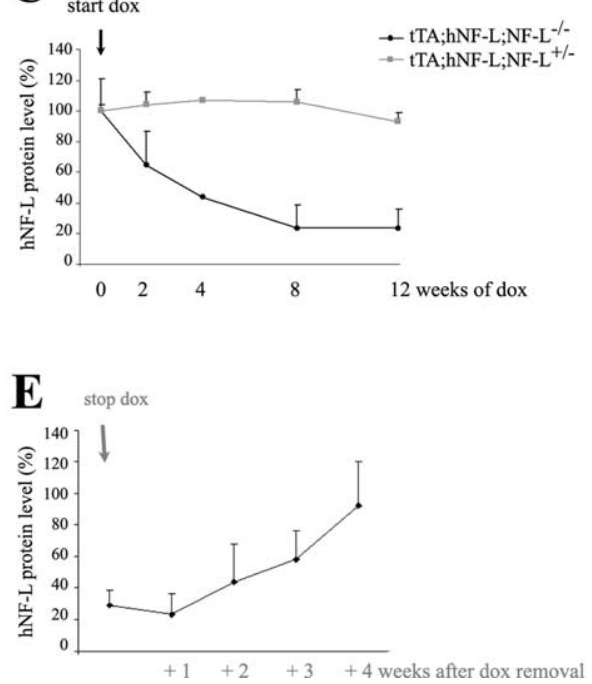

Figure 4. Turnover and transport of $h N F-L$ protein in the sciatic nerve. $A$, Semiquantitative reverse transcription (RT)-PCR for hNF-L mRNA showing the decrease of expression in the DRG after 1 and 2 weeks of doxycycline (dox) treatment in (tTA;hNF-L;NF-

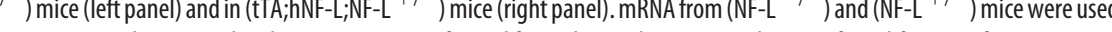
as negative controls. A control without RTase was performed for each sample to ensure absence of amplification of genomic DNA. In (tTA;hNF-L;NF-L ${ }^{+/-}$) mice, RT-PCR-amplified NF-L fragments ( $589 \mathrm{bp}$ ) were digested by Xhol, a restriction site cutting the divided in two fragments of 325 and $264 \mathrm{bp}$. Note that the endogenous mouse NF-L expression is not changed by cessation of (t) expression in (tT;NF-L;NF-L ${ }^{+-}$) mice. $\boldsymbol{B}$, Western blot analysis of hNF-L expression in the consecutive $6 \mathrm{~mm}$ segments (left) and (tTA;hNF-L;NF-L ${ }^{+/-}$) mice (right) at $0,2,4$, and 12 weeks after starting up the doxycycline treatment $C$ Densitometric analysis of NF-L protein level for (tTA;hNF-L;NF-L ${ }^{-I^{-}}$) (black curve) and (tTA;hNF-L;NF-L ${ }^{+/-}$) (gray curve) mice at each time point during the course of doxycycline treatment. Results are means \pm SEM of three to nine animals per time point except for the 4 weeks time point determination (1 animal). Note the progressive decline of NF-L protein level after the start up of doxycycline D, Western blot analysis of NF-L (left), NF-M, and NF-H (right) expression in (tTA;hNF-L;NF-L ${ }^{-1-}$ ) mice after cessation of doxycycline treatment. $\boldsymbol{E}$, Means \pm SEM of densitometric measures of NF-L level recorded from 5 to 10 animals per time point. Two weeks after cessation of doxycycline treatment, the NF-L protein reappeared and accumulated progressively at similar rates in each segment of the sciatic nerve in (tTA; hNF-L;NF- $\mathrm{L}^{-1-}$ ) mice.

newly synthesized NF proteins had moved into the $6 \mathrm{~mm}$ distal segment of the nerve (Fig. 5C,D). Thus, we estimate that the rate of NF transport was one order of magnitude faster $(\sim 10 \mathrm{~mm} / \mathrm{d})$ in absence of preexisting stationary NF network in axons of (hNF-L;NF-L ${ }^{-1-}$ ) mice.

We performed the same experiment in (hNF-L;NF-L ${ }^{+/-}$) mice to confirm that the rate of hNF-L axonal transport is slower in axons with established stationary NF network. Similar to what we observed in (hNF-L;NF-L ${ }^{-1-}$ ) mice, the hNF-L-triggered protein in (hNF-L;NF-L ${ }^{+/-}$) mice was detectable in the proximal segment of the hypoglossal nerve at $2 \mathrm{~d}$ (D2) after adenovirus injection (Fig. 5E, black arrow, $F$ ). However, unlike the situation with (hNF-L;NF-L ${ }^{-1-}$ ) mice, the newly made hNF-L protein in the context of mouse NF-L background did not reach the distal segment of the sciatic nerve at $5 \mathrm{~d}$ (D5) after adenovirus injection. 
A
3. Expression of hNF-L in
motoneuron cell bodies of XII nucleus

4. Anterograde axonal transport of hNF-L protein in the XII nerve

B

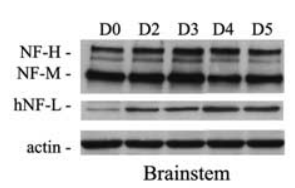

C

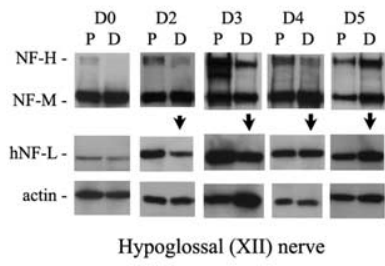

Hypoglossal (XII) nerve

D
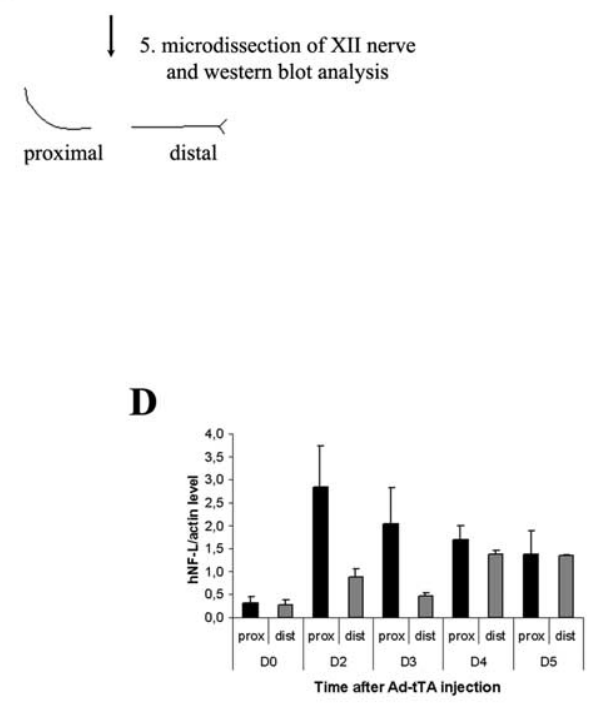

$\mathbf{F}$

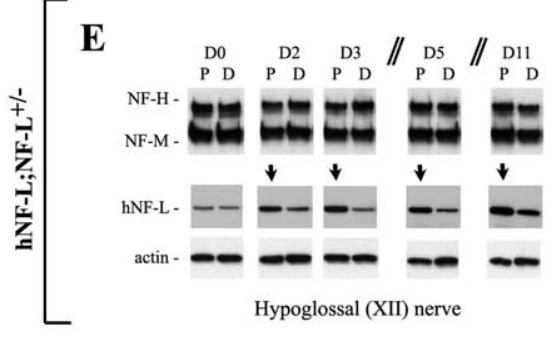
vector in the XII nerve

1. Injection of Ad-tTA into the mouse tongue

microdissection of XII nerve
Retrograde transport of the

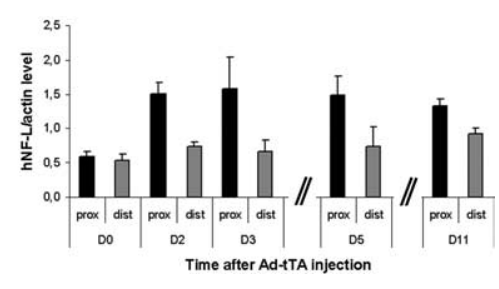

Figure 5. Faster transport of hNF-L protein in axons devoid of stationary NF network. $A$, Schematic representation of the successive steps of the experimental design. Ad-tTA was injected into the tongue muscles of (hNF-L;NF-L ${ }^{-/-}$) mice (1). After retrograde transport of the adenoviral vector along the hypoglossal (XII) nerve (2), the tTA triggered expression of hNF-L in the motoneuron cell bodies of the XII nucleus (3). hNF-L protein was transported down the XII nerve (4). The right and left branches of the hypoglossal nerve were dissected out (5) and divided in a proximal segment (1-6 $\mathrm{mm}$ from the cell body) and a distal segment (7-12 mm from the cell body). $\boldsymbol{B}-\boldsymbol{F}$, Protein expression analysis after injection of Ad-tTA in (hNF-L;NF-L ${ }^{-1-}$ ) mice $(\boldsymbol{B}-\boldsymbol{D})$ and in (hNF-L;NF-L ${ }^{+/-}$) mice $(\boldsymbol{E}, \boldsymbol{F})$. Western blot analysis in the brainstem of (hNF-L;NF-L ${ }^{-1-}$ ) mice before (DO) and 2, 3, 4, and $5 \mathrm{~d}$ (D2, D3, D4, and D5) after Ad-tTA injection (B). Western blot analysis in the proximal (P) and distal (D) portions of the XII nerve before (D0) and from 2-11 d (D2-D11) after Ad-TTA injection. For each animal, densitometric values of hNF-L expression were recorded in the proximal (black) and distal (gray) segments of the nerve and reported to that of actin. Data are means \pm SEM of two to three animals $(\boldsymbol{D})$ and of five to seven animals $(\boldsymbol{F})$ per time point.

At $11 \mathrm{~d}$ (D11) after Ad-tTA injection (last time analyzed), the hNF-L protein became detectable in the distal segment, but it was less abundant than in the proximal nerve segment. These results are consistent with a slow axonal transport of hNF-L (rate of $\sim 1$ $\mathrm{mm} / \mathrm{d})$ in the hypoglossal nerve of $\left(\mathrm{NF}^{-\mathrm{L}^{+/-}}\right)$mice having stationary mouse NF network. Thus, the axonal transport of hNF-L was faster in axons devoid of NFs (NF- $\mathrm{L}^{-1-}$ mice) than in axons with pre-existing mouse NF network (NF-L ${ }^{+/-}$mice).

\section{Discussion}

Transgenic mice with doxycycline control of hNF-L expression allowed us to investigate the in vivo turnover of NF proteins. The hNF-L mRNA expression was turned off throughout the nervous system after only 1 week administration of doxycycline. However, the NF-L proteins persisted for much longer time. In the cerebellum, we calculated that the NF-L protein has a half-life of $\sim 3$ weeks. These results are very consistent with the halflives of NF proteins previously estimated from the decay of $\left[{ }^{3} \mathrm{H}\right]$ proline radiolabeling proteins in retinal ganglion cell axons (Nixon and Logvinenko, 1986). This study reported the degradation of radiolabeled NF proteins in two exponential rates. There was a rapid loss $(\sim 10 \%$ per week) of radiolabeled NF proteins during 6 weeks $\left(t_{1 / 2}=20 \mathrm{~d}\right)$ followed by a slower loss $(\sim 1.5 \%$ per week) during 4 months $\left(t_{1 / 2}=55 \mathrm{~d}\right)$. Similarly, our results revealed a biphasic disappearance of NFs in the cerebellum after doxycycline administration in mice (Fig. 3E). In our study, hNF-L disappearance showed a first decrease $(\sim 13-15 \%$ per week) during 4 weeks both in (NF-L $\left.{ }^{-/-}\right)$and (NF- $\mathrm{L}^{+/-}$) mice. Then, the decrease slowed down (loss of $\sim 3-5 \%$ per week) for 2 months.

In addition, our study indicates that the longevity of NF proteins can be greatly increased in large-caliber axons with a high content of NF structures. Thus, after 3 months of doxycycline treatment of (tTA;hNF-L;NF-L ${ }^{+/-}$) mice that maintained the existence of NF network through mouse NF-L expression, there was no significant reduction of hNF-L protein levels in sciatic nerve axons (Fig. $4 B, C$ ) compared with CNS neurons (Fig. $3 D, E)$. This emphasizes the importance of a stationary NF network as a factor that slows down the turnover rate of NFs in the axon. This is expected to vary in different neuronal types and during neuronal development. Our data would support the notion that NF proteins might last several months or even years in long peripheral axons with dense NF network.

In transgenic mice lacking endogenous mouse NF-L, we did not observe a trailing wave of moving hNF-L proteins that would have corresponded to the disappearance of the protein from the proximal segments after doxycycline treatment (Fig. $4 B)$. Such waves are detectable in classical kinetics of disappearance of radiolabeled NF proteins distributed along axons (Nixon and Logvinenko, 1986). In contrast, here, the loss of NF-L proteins occurred in apparent synchrony along the sciatic nerve. This suggests that proteolysis of hNF-L proteins occurred along the entire nerve and that it was not limited to the nerve ending. An alternative explanation for this result is that, in the absence of new NF-L supply, small fractions of hNF-L could quit the stationary pool to join a fast moving pool along the entire axon with ensuing degradation at the axon terminals. These two mechanism models are not mutually exclusive. Little is known about proteolysis of NFs in vivo. Axonal proteolysis of NFs has been reported during Wallerian degeneration in transected fragments of nerve (Schlaepfer, 1974). In such experiments, NFs are degraded in situ in excised segments of peripheral nerve, suggest- 
ing that degrading enzymes are active not only at synaptic endings but also locally in axons. A local degradation of NF proteins in axons was proposed previously as a mechanism to explain nonhomogeneous distribution of NFs in axons (Nixon and Logvinenko, 1986).

Unexpectedly, after cessation of doxycycline treatment in (tTA;hNF-L;NF-L ${ }^{-1-}$ ) mice, the newly synthesized NF-L proteins detected at 1 week intervals reappeared and accumulated simultaneously along segments of the sciatic nerve (Fig. 4D). There was no front wave of hNF-L moving at $\sim 1 \mathrm{~mm} / \mathrm{d}$ according to classical in vivo radiolabeling experiments with amino acid precursors injected in normal animals. At this slow transport rate, the hNF-L should have remained in the first $12 \mathrm{~mm}$ segments after 2 weeks. Instead, the hNF-L band was distributed equally along the entire nerve after reactivation of transgene expression. It is implausible that this is attributable to transport and local translation of NF mRNA along the axons, because studies performed on cultured neuronal cells failed to visualize the presence of NF-L mRNA in neurites by in situ analysis (Kleiman et al., 1990; Litman et al., 1994), and protein synthesis in distal axons represent $<1 \%$ of total neuronal synthesis with the major proteins corresponding to actin and $\beta$-tubulin (Eng et al., 1999).

The most plausible explanation for this phenomenon is that NF proteins moved in vivo at a faster transport rate here, because axons were devoid of preexisting NF structures. As shown in Figure 5, the use of a tTA adenoviral vector to trigger hNF-L synthesis in the hypoglossal motoneurons of (hNF-L;NF-L ${ }^{-1-}$ ) and (hNF-L;NF-L ${ }^{+/-}$) mice further provided in vivo evidence of faster transport of hNF-L protein in axons devoid of NFs than in axons with preexisting NF network. We estimate that the rate of NF transport was enhanced by one order of magnitude $(\sim 10$ $\mathrm{mm} / \mathrm{d}$ ) in axons empty of NF network. Actually, these results are in line with the visualization of fast movement of fluorescenttagged NF proteins that was obtained previously with the use of cultured sympathetic neurons exhibiting gaps in their NF network (Roy et al., 2000; Wang et al., 2000). From these studies, the $\mathrm{NF}$ transport kinetic in NF-depleted (NF-L ${ }^{-/-}$) axons would range from 3 to $14 \mathrm{~mm} / \mathrm{d}$, estimated from the average transport rate of $0.23 \mu \mathrm{m} / \mathrm{s}$ during $15 \%$ of the time (Wang et al., 2000) and the average rate of $0.79 \mu \mathrm{m} / \mathrm{s}$ during $20 \%$ of the time (Roy et al., 2000), respectively. Thus, the rate of $\sim 10 \mathrm{~mm} / \mathrm{d}$ estimated in our study is in the range of those reported with in vitro studies of sympathetic axons with low NF content. Here, our studies with the reactivation of hNF-L transgene in mice provide the first in vivo demonstration of faster NF transport in the context of NF network deficiency. The rate of $\sim 10 \mathrm{~mm} / \mathrm{d}$ is similar to the range of the slow component $\mathrm{b}$ carrying microfilaments and spectrin $(2-8 \mathrm{~mm} / \mathrm{d})$.

The NF-M protein was detected in the hypoglossal nerve of $\left(\mathrm{NF}-\mathrm{L}^{-1-}\right.$ ) mice (Fig. $5 C$ ). The presence of NF-M in the NF$\mathrm{L}^{-/-}$axons is not too surprising considering previous studies. For instance, there was axonal transport of NF-M after injection of a recombinant adenovirus encoding a tagged-NF-M protein in the DRG of transgenic mice in which axons lack NF arrays (Terada et al., 1996). Moreover, analysis of NF-L ${ }^{-1-}$ mice showed a substantial proportion of the NF-M protein (52\%) in optic axons (Yuan et al., 2003). These combined results support the view that NF-M is capable of transport into axons in the absence of NF-L. This could be attributable to, in part, the ability of NF-M to be transported in an unpolymerized form (monomer or small oligomers) along microtubules (Terada et al., 1996) or in association with $\alpha$-internexin protein (Yuan et al., 2003, 2006).

It is expected that the NF transport rate might differ in neu-

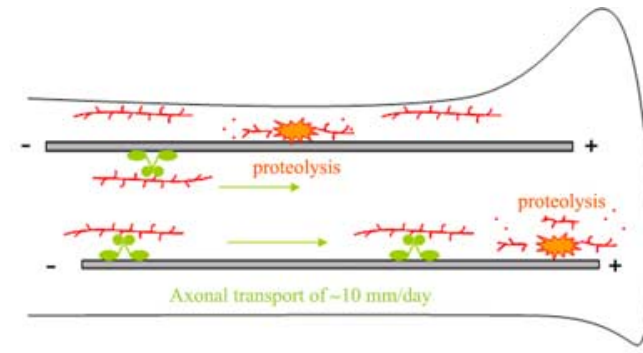

Axons with

low NF content

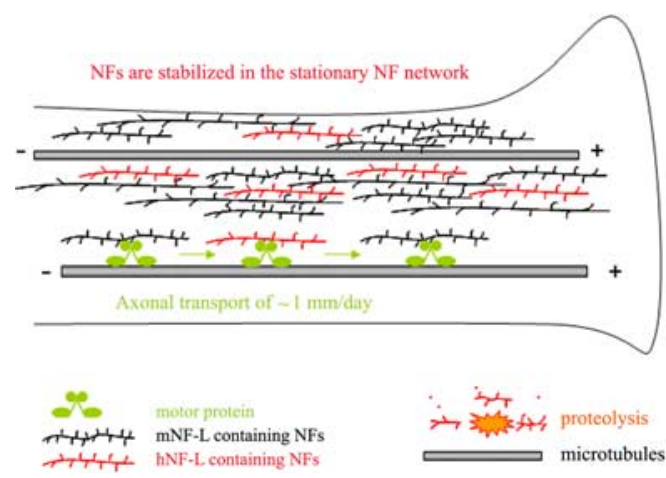

Axons with high NF content

Figure 6. A model for the transport rate and the half-life of hNF-L in axons. In axons with a low content of NFs, hNF-L protein is transported faster $(\sim 10 \mathrm{~mm} / \mathrm{d})$ than in axons with a high content of NF array $(\sim 1 \mathrm{~mm} / \mathrm{d})$. This may be attributable to the decreased number of pauses they make during their travel along the nerve and/or to the decreased interactions they can establish with the stationary pool. Moreover in the absence of NFs supply, a small fraction of hNF-L comes out of the stationary pool and is degraded either along the entire nerve or after migrating to the axon terminal. In axons with prominent NF network, the hNF-L protein is stabilized by the stationary pool. It remains a longer time in pauses, and it is less susceptible to proteolytic degradation. Thus, the stationary NFs network is a determinant of half-life and axonal transport rate of NF-L proteins.

ronal cell types with different NF content. It is known that the rate of slow axonal transport is lower in adult than in young animals (Lasek, 1970; Hendrickson and Cowan, 1971; Komiya, 1980; Hoffman et al., 1983). Indeed NFs are transported in optic nerve at a rate of eight times faster during the postnatal development than that observed in adult animals (Willard and Simon, 1983), and the decrease in the transport rate of NFs coincides with the increase in the number of NFs in axons (Hoffman et al., 1983). Here, our data provide proof that the transport rate of NF proteins is strongly influenced by the presence of an NF network (Fig. 6). The axonal transport rate of NFs is determined primarily by the time NFs remain associated with the stationary cytoskeleton. Factors that determine the pauses of NF proteins in stationary NFs are mostly unknown. Phosphorylation, myelination, and axonal caliber are possible factors involved in the slowing of axonal transport. Glutamate can slow down NF transport in cultured neurons through a possible glutamate-activated kinase pathway that phosphorylates NFs (Ackerley et al., 2000). Because the phosphorylation of tail domains of NF-M and NF-H during the development can trigger the local accumulation of NFs in axons (Lewis and Nixon, 1988; Nixon et al., 1994), this process may also be involved in the association of individual NFs with a stationary NF lattice. In support of this view, the rate of NF transport was found to slow down progressively along axons, and this correlated with the degree of phosphorylation of NFs (Archer et al., 1994; Xu and Tung, 2001; Jung and Shea, 2004).

The stoichiometry of IF proteins is a factor known to influence the axonal transport of NFs. The axonal transport of NF proteins was slowed down after NF-H or NF-M overexpression in mice 
(Collard et al., 1995; Marszalek et al., 1996; Xu and Tung, 2000) as well as by excess of peripherin (Millecamps et al., 2006). NF transport in the sciatic nerve was found to be increased after NF-H or NF-M deletion (Zhu et al., 1998; Jacomy et al., 1999). However, deleting the NF-H or NF-M tail did not affect the NF transport rate in the optic nerve (Rao et al., 2002, 2003; Yuan et al., 2006a). Results may differ from different types of axons, and perhaps the axonal transport rate reflects variations in content of molecular motors and/or other IFs interacting proteins.

Abnormal distribution of NFs may occur after chronic exposure to certain chemicals. Neuropathies are sometimes associated with massive focal accumulations of NFs along myelinated axons either in their distal part, such as intoxication with 2,5hexanedione and carbon disulfide industrial solvents, or in their proximal segment, such as in $\beta \beta^{\prime}$-iminodipropionitrile (IDPN) or aluminum salts intoxication. Through covalent modifications of NF proteins or phosphorylation changes, these agents could destabilize interactions between NFs and other cytoskeletal components, which are essential for normal slow axonal transport (Sayre et al., 1985). Interestingly, after exposure to 2,5hexanedione and carbon disulfide the NF transport was found to be faster, whereas the NF content in proximal segment of the axon was decreased (Monaco et al., 1985, 1989; Pappolla et al., 1987). In contrast, the NF transport is severely delayed after IDPN or aluminum salt intoxications (Bizzi et al., 1984; Griffin et al., 1985; Parhad et al., 1986). These observations are in line with a NF transport rate that is influenced by the NF content in axons. Moreover, the exceedingly low turnover rate of NFs observed in our studies could explain the persistence of NF accumulations a long time after exposure to neurotoxic compounds.

Axonal accumulations of NF proteins are also observed in many neurodegenerative diseases, including motor neuron diseases and sensorimotor neuropathies. For instance, proximal axonal enlargements called spheroids are found amyotrophic lateral sclerosis (Carpenter, 1968; Hirano et al., 1984a,b; Corbo and Hays, 1992). Giant axons filled with segmental packed NF proteins are pathological characteristics of giant axonal neuropathy (Asbury et al., 1972; Bomont et al., 2000). Such disorganized NFs are probably the result of defective turnover or transport of NF proteins along the axons. Moreover, the long life of NFs makes them potential targets for oxidation or other deleterious modifications, which in turn may contribute to exacerbate axonal defects.

\section{References}

Ackerley S, Grierson AJ, Brownlees J, Thornhill P, Anderton BH, Leigh PN, Shaw CE, Miller CC (2000) Glutamate slows axonal transport of neurofilaments in transfected neurons. J Cell Biol 150:165-176.

Archer DR, Watson DF, Griffin JW (1994) Phosphorylation-dependent immunoreactivity of neurofilaments and the rate of slow axonal transport in the central and peripheral axons of the rat dorsal root ganglion. J Neurochem 62:1119-1125.

Asbury AK, Gale MK, Cox SC, Baringer JR, Berg BO (1972) Giant axonal neuropathy-a unique case with segmental neurofilamentous masses. Acta Neuropathol (Berl) 20:237-247.

Bizzi A, Crane RC, Autilio-Gambetti L, Gambetti P (1984) Aluminum effect on slow axonal transport: a novel impairment of neurofilament transport. J Neurosci 4:722-731.

Bomont P, Cavalier L, Blondeau F, Ben Hamida C, Belal S, Tazir M, Demir E, Topaloglu H, Korinthenberg R, Tuysuz B, Landrieu P, Hentati F, Koenig M (2000) The gene encoding gigaxonin, a new member of the cytoskeletal BTB/kelch repeat family, is mutated in giant axonal neuropathy. Nat Genet 26:370-374.

Borchelt DR, Davis J, Fischer M, Lee MK, Slunt HH, Ratovitsky T, Regard J, Copeland NG, Jenkins NA, Sisodia SS, Price DL (1996) A vector for expressing foreign genes in the brains and hearts of transgenic mice. Genet Anal 13:159-163.

Brown A (2000) Slow axonal transport: stop and go traffic in the axon. Nat Rev Mol Cell Biol 1:153-156.

Carpenter S (1968) Proximal axonal enlargement in motor neuron disease. Neurology 18:841-851.

Ching GY, Liem RK (1993) Assembly of type IV neuronal intermediate filaments in nonneuronal cells in the absence of preexisting cytoplasmic intermediate filaments. J Cell Biol 122:1323-1335.

Collard JF, Cote F, Julien JP (1995) Defective axonal transport in a transgenic mouse model of amyotrophic lateral sclerosis. Nature 375:61-64.

Corbo M, Hays AP (1992) Peripherin and neurofilament protein coexist in spinal spheroids of motor neuron disease. J Neuropathol Exp Neurol 51:531-537.

Corti O, Sabate O, Horellou P, Colin P, Dumas S, Buchet D, Buc-Caron MH, Mallet J (1999) A single adenovirus vector mediates doxycyclinecontrolled expression of tyrosine hydroxylase in brain grafts of human neural progenitors. Nat Biotechnol 17:349-354.

Cote F, Collard JF, Julien JP (1993) Progressive neuronopathy in transgenic mice expressing the human neurofilament heavy gene: a mouse model of amyotrophic lateral sclerosis. Cell 73:35-46.

Eng H, Lund K, Campenot RB (1999) Synthesis of $\beta$-tubulin, actin, and other proteins in axons of sympathetic neurons in compartmented cultures. J Neurosci 19:1-9.

Finiels F, Gimenez y Ribotta M, Barkats M, Samolyk ML, Robert JJ, Privat A, Revah F, Mallet J (1995) Specific and efficient gene transfer strategy offers new potentialities for the treatment of motor neurone diseases. NeuroReport 7:373-378.

Ghadge GD, Roos RP, Kang UJ, Wollmann R, Fishman PS, Kalynych AM, Barr E, Leiden JM (1995) CNS gene delivery by retrograde transport of recombinant replication-defective adenoviruses. Gene Ther 2:132-137.

Gossen M, Bujard H (1992) Tight control of gene expression in mammalian cells by tetracycline-responsive promoters. Proc Natl Acad Sci USA 89:5547-5551.

Griffin JW, Parhad I, Gold B, Price DL, Hoffman PN, Fahnestock K (1985) Axonal transport of neurofilament proteins in IDPN neurotoxicity. Neurotoxicology 6:43-53.

Hendrickson AE, Cowan WM (1971) Changes in the rate of axoplasmic transport during postnatal development of the rabbit's optic nerve and tract. Exp Neurol 30:403-422.

Hirano A, Donnenfeld H, Sasaki S, Nakano I (1984a) Fine structural observations of neurofilamentous changes in amyotrophic lateral sclerosis. J Neuropathol Exp Neurol 43:461-470.

Hirano A, Nakano I, Kurland LT, Mulder DW, Holley PW, Saccomanno G (1984b) Fine structural study of neurofibrillary changes in a family with amyotrophic lateral sclerosis. J Neuropathol Exp Neurol 43:471-480.

Hoffman PN, Lasek RJ (1975) The slow component of axonal transport. Identification of major structural polypeptides of the axon and their generality among mammalian neurons. J Cell Biol 66:351-366.

Hoffman PN, Lasek RJ, Griffin JW, Price DL (1983) Slowing of the axonal transport of neurofilament proteins during development. J Neurosci 3:1694-1700.

Hoffman PN, Griffin JW, Price DL (1984) Control of axonal caliber by neurofilament transport. J Cell Biol 99:705-714.

Jacomy H, Zhu Q, Couillard-Despres S, Beaulieu JM, Julien JP (1999) Disruption of type IV intermediate filament network in mice lacking the neurofilament medium and heavy subunits. J Neurochem 73:972-984.

Julien JP, Tretjakoff I, Beaudet L, Peterson A (1987) Expression and assembly of a human neurofilament protein in transgenic mice provide a novel neuronal marking system. Genes Dev 1:1085-1095.

Jung C, Shea TB (2004) Neurofilament subunits undergo more rapid translocation within retinas than in optic axons. Brain Res Mol Brain Res 122:188-192.

Kleiman R, Banker G, Steward O (1990) Differential subcellular localization of particular mRNAs in hippocampal neurons in culture. Neuron 5:821-830.

Komiya Y (1980) Slowing with age of the rate of slow axonal flow in bifurcating axons of rat dorsal root ganglion cells. Brain Res 183:477-480.

Lasek RJ (1970) Axonal transport of proteins in dorsal root ganglion cells of the growing cat: a comparison of growing and mature neurons. Brain Res 20:121-126. 
Lasek RJ, Paggi P, Katz MJ (1992) Slow axonal transport mechanisms move neurofilaments relentlessly in mouse optic axons. J Cell Biol 117:607-616.

Lee MK, Xu Z, Wong PC, Cleveland DW (1993) Neurofilaments are obligate heteropolymers in vivo. J Cell Biol 122:1337-1350.

Lewis SE, Nixon RA (1988) Multiple phosphorylated variants of the high molecular mass subunit of neurofilaments in axons of retinal cell neurons: characterization and evidence for their differential association with stationary and moving neurofilaments. J Cell Biol 107:2689-2701.

Litman P, Barg J, Ginzburg I (1994) Microtubules are involved in the localization of tau mRNA in primary neuronal cell cultures. Neuron 13:1463-1474.

Marszalek JR, Williamson TL, Lee MK, Xu Z, Hoffman PN, Becher MW, Crawford TO, Cleveland DW (1996) Neurofilament subunit NF-H modulates axonal diameter by selectively slowing neurofilament transport. J Cell Biol 135:711-724.

Millecamps S, Julien JP (2004) $\left[{ }^{35}\right.$ S $]$ Methionine metabolic labeling to study axonal transport of neuronal intermediate filament proteins in vivo. Methods Cell Biol 78:555-571.

Millecamps S, Kiefer H, Navarro V, Geoffroy MC, Robert JJ, Finiels F, Mallet J, Barkats M (1999) Neuron-restrictive silencer elements mediate neuron specificity of adenoviral gene expression. Nat Biotechnol 17:865-869.

Millecamps S, Nicolle D, Ceballos-Picot I, Mallet J, Barkats M (2001) Synaptic sprouting increases the uptake capacities of motoneurons in amyotrophic lateral sclerosis mice. Proc Natl Acad Sci USA 98:7582-7587.

Millecamps S, Robertson J, Lariviere R, Mallet J, Julien JP (2006) Defective axonal transport of neurofilament proteins in neurons overexpressing peripherin. J Neurochem 98:926-938.

Monaco S, Autilio-Gambetti L, Zabel D, Gambetti P (1985) Giant axonal neuropathy: acceleration of neurofilament transport in optic axons. Proc Natl Acad Sci USA 82:920-924.

Monaco S, Autilio-Gambetti L, Lasek RJ, Katz MJ, Gambetti P (1989) Experimental increase of neurofilament transport rate: decreases in neurofilament number and in axon diameter. J Neuropathol Exp Neurol 48:23-32.

Nixon RA, Logvinenko KB (1986) Multiple fates of newly synthesized neurofilament proteins: evidence for a stationary neurofilament network distributed nonuniformly along axons of retinal ganglion cell neurons. J Cell Biol 102:647-659.

Nixon RA, Paskevich PA, Sihag RK, Thayer CY (1994) Phosphorylation on carboxyl terminus domains of neurofilament proteins in retinal ganglion cell neurons in vivo: influences on regional neurofilament accumulation, interneurofilament spacing, and axon caliber. J Cell Biol 126:1031-1046.

Pappolla M, Penton R, Weiss HS, Miller Jr CH, Sahenk Z, Autilio-Gambetti L, Gambetti P (1987) Carbon disulfide axonopathy. Another experimental model characterized by acceleration of neurofilament transport and distinct changes of axonal size. Brain Res 424:272-280.

Parhad IM, Griffin JW, Hoffman PN, Koves JF (1986) Selective interruption of axonal transport of neurofilament proteins in the visual system by beta,beta'-iminodipropionitrile (IDPN) intoxication. Brain Res 363:315-324

Rao MV, Garcia ML, Miyazaki Y, Gotow T, Yuan A, Mattina S, Ward CM, Calcutt NA, Uchiyama Y, Nixon RA, Cleveland DW (2002) Gene replacement in mice reveals that the heavily phosphorylated tail of neurofilament heavy subunit does not affect axonal caliber or the transit of cargoes in slow axonal transport. J Cell Biol 158:681-693.

Rao MV, Campbell J, Yuan A, Kumar A, Gotow T, Uchiyama Y, Nixon RA
(2003) The neurofilament middle molecular mass subunit carboxylterminal tail domains is essential for the radial growth and cytoskeletal architecture of axons but not for regulating neurofilament transport rate. J Cell Biol 163:1021-1031.

Roy S, Coffee P, Smith G, Liem RK, Brady ST, Black MM (2000) Neurofilaments are transported rapidly but intermittently in axons: implications for slow axonal transport. J Neurosci 20:6849-6861.

Sande MA, Mandell GL (1990) Tetracycline, chloramphenicol, erythromycin and miscellaneous antibiotic agents. New York: Pergamon.

Sayre LM, Autilio-Gambetti L, Gambetti P (1985) Pathogenesis of experimental giant neurofilamentous axonopathies: a unified hypothesis based on chemical modification of neurofilaments. Brain Res 357:69-83.

Schlaepfer WW (1974) Calcium-induced degeneration of axoplasm in isolated segments of rat peripheral nerve. Brain Res 69:203-215.

Tanaka Y, Igarashi S, Nakamura M, Gafni J, Torcassi C, Schilling G, Crippen D, Wood JD, Sawa A, Jenkins NA, Copeland NG, Borchelt DR, Ross CA, Ellerby LM (2006) Progressive phenotype and nuclear accumulation of an amino-terminal cleavage fragment in a transgenic mouse model with inducible expression of full-length mutant huntingtin. Neurobiol Dis 21:381-391.

Terada S, Nakata T, Peterson AC, Hirokawa N (1996) Visualization of slow axonal transport in vivo. Science 273:784-788.

Tremblay P, Meiner Z, Galou M, Heinrich C, Petromilli C, Lisse T, Cayetano J, Torchia M, Mobley W, Bujard H, DeArmond SJ, Prusiner SB (1998) Doxycycline control of prion protein transgene expression modulates prion disease in mice. Proc Natl Acad Sci USA 95:12580-12585.

Wang L, Ho CL, Sun D, Liem RK, Brown A (2000) Rapid movement of axonal neurofilaments interrupted by prolonged pauses. Nat Cell Biol 2:137-141.

Willard M, Simon C (1983) Modulations of neurofilament axonal transport during the development of rabbit retinal ganglion cells. Cell 35:551-559.

Xu Z, Tung VW (2000) Overexpression of neurofilament subunit M accelerates axonal transport of neurofilaments. Brain Res 866:326-332.

$\mathrm{Xu} \mathrm{Z}$, Tung VW (2001) Temporal and spatial variations in slow axonal transport velocity along peripheral motoneuron axons. Neuroscience 102:193-200.

Yabe JT, Jung C, Chan WK, Shea TB (2000) Phospho-dependent association of neurofilament proteins with kinesin in situ. Cell Motil Cytoskeleton 45:249-262.

Yuan A, Rao MV, Kumar A, Julien JP, Nixon RA (2003) Neurofilament transport in vivo minimally requires hetero-oligomer formation. J Neurosci 23:9452-9458.

Yuan A, Nixon RA, Rao MV (2006a) Deleting the phosphorylated tail domain of the neurofilament heavy subunit does not alter neurofilament transport rate in vivo. Neurosci Lett 393:264-268.

Yuan A, Rao MV, Sasaki T, Chen Y, Kumar A, Veeranna, Liem RK, Eyer J, Peterson AC, Julien JP, Nixon RA (2006b) $\alpha$-Internexin is structurally and functionally associated with the neurofilament triplet proteins in the mature CNS. J Neurosci 26:10006-10019.

Zhu Q, Couillard-Despres S, Julien JP (1997) Delayed maturation of regenerating myelinated axons in mice lacking neurofilaments. Exp Neurol 148:299-316

Zhu Q, Lindenbaum M, Levavasseur F, Jacomy H, Julien JP (1998) Disruption of the NF-H gene increases axonal microtubule content and velocity of neurofilament transport: relief of axonopathy resulting from the toxin beta,beta'-iminodipropionitrile. J Cell Biol 143:183-193. 